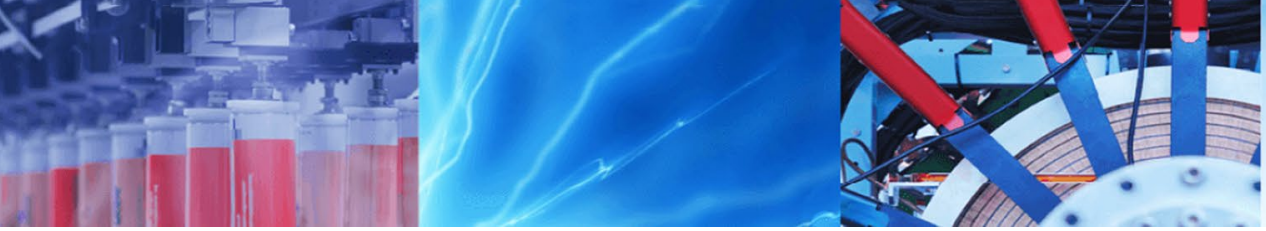

Research Article

\title{
The symmetrical and asymmetrical effects of foreign direct investment and financial development on carbon emission: evidence from Nigeria
}

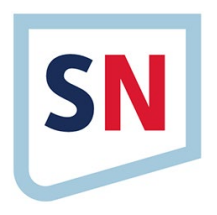

\author{
Jamiu Adetola Odugbesan $^{1}$ (D) . Tomiwa Sunday Adebayo ${ }^{1}$ (D)
}

Received: 17 August 2020 / Accepted: 31 October 2020 / Published online: 11 November 2020

(c) Springer Nature Switzerland AG 2020

\begin{abstract}
This study aimed at investigating the symmetric and asymmetric effects of financial development, foreign direct investment (FDI), energy consumption, and economic growth on carbon emissions $\left(\mathrm{CO}_{2}\right)$ towards environmental sustainability in Nigeria. A yearly data spanning from 1981 to 2016 was utilized with linear ARDL and non-linear ARDL techniques. The findings from the estimations show that FDI, and energy consumption have a long-run linear relationship with $\mathrm{CO}_{2}$ in Nigeria. In addition, FDI has a linear relationship with $\mathrm{CO}_{2}$ in the short-run. Interestingly, the positive and negative shocks in FDI have a significant long-run relationship with $\mathrm{CO}_{2}$, while only positive shock in financial development has a long-run relationship with $\mathrm{CO}_{2}$. The asymmetric effect in the short-run from the estimation shows that the positive and negative shocks in both financial development and FDI have a short-run relationship with $\mathrm{CO}_{2}$. Thus, this study argues for the integration of nationwide social awareness programs in the environmental policies and the implementation of financial credit policy that will address environmental degradation in Nigeria.
\end{abstract}

Keywords Environmental sustainability · Carbon emission · Financial development · Foreign direct investment . Symmetric and asymmetric effect · Nigeria

JEL Classification B22 $\cdot \mathrm{C} 01 \cdot \mathrm{C} 54 \cdot \mathrm{O} 13 \cdot \mathrm{P} 18$

\section{Introduction}

Several studies have alluded to the report of the "Intergovernmental Panel on Climate Change" that the issues of climate change and global warming have become a significant global issue in the past decades since it was observed that the carbon emission had been significantly increasing $[67,77]$. This scenario has resulted in the struggle of different organizations to reduce the adverse impact of global warming by committing different countries to an agreement like the Kyoto Protocol [44]. Meanwhile, Kutney [59] observed that while several countries signed the "Kyoto Protocol," the United States, which is considered the largest emitter per capita in the world, refused to ratify the agreement, thus creating a challenge for the success of the treaty. Nigeria was among the 192 parties that have signed the Kyoto Protocol as of 2013 [29]. Meanwhile, the idea of an international equitable burdensharing arrangement to control and ameliorate carbon emissions based on multilaterally negotiated binding emissions targets and time table for each country was jettisoned with the official launching of "Paris Climate Agreement" in 2015 (Clemencon 2016). However, worthy to note that the Paris agreement is built entirely around voluntary country pledges which are still far from summing up to achieving the objectives the agreement defines. It was posited in the World Bank Report [105] that carbon dioxide $\left(\mathrm{CO}_{2}\right)$ is a significant pollutant among the pollutants

$\triangle$ Jamiu Adetola Odugbesan, odugbesanadetola@gmail.com; Tomiwa Sunday Adebayo, Twaikline@gmail.com | ${ }^{1}$ Department of Business Administration, Faculty of Economic and Administrative Science, Cyprus International University, Northern Cyprus, Nicosia, Mersin 10, Turkey. 
that result in climate change due to its contribution of about $58.8 \%$ of the "Greenhouse Gases (GHG)" emission. Thus, the policymakers realized that it becomes imperative to reduce carbon emission [41]. Asumadu-Sarkodie and Owusu [18] observed that due to the rapidly growing economy of some developing countries, the larger portion of carbon-dioxide is emanating from there. AsumaduSakordie, Sevinc and Jayaweera (2016) posited that "Sustainable Development Goal 13" emphasized that in every country around the world; there should be an inclusion in the national policies, the planning and strategy that will be aimed at the measurement of climate change. This becomes necessary because environmental pollution is believed to have a significant impact on human health, leading to social problems [73].

According to PACJA (2009), Africa climate will be more volatile with high level of uncertainty, especially West Africa's temperature, which is part of Sahel zone that has raised a significant trend than the global. For instance, Nigeria was predicted by DFID (2009) that there would be a rise in sea level that will be around $0.3 \mathrm{~m}$ by 2020 , and increase to $1 \mathrm{~m}$ by 2050, while the temperature will be about $3.2^{\circ} \mathrm{C}$ by 2050 . The implication of the predicted rise in sea level for Nigeria may lead to the loss of large portion of the Niger Delta region through flooding [29], thus the need to check the rise of carbon emission in Nigeria. Meanwhile, burning of fossil fuels is considered to be one of the determinants of carbon emission [75], whereas, Nigeria economy is highly dependent on fossil fuels owing to its abundance of crude oil in the country (OPEC 2019), which has in no doubt created significant environmental concern for the stakeholders [84]. Elum and Momodu [36] and Riti and Shu [84] observed that the dependence of industrial, transportation, and commercial sectors on fossil fuels and its burning remains the major drivers of $\mathrm{CO}_{2}$ emissions in Nigeria, especially in the urban areas where the activities of private sectors generate high demand for energy. The "Energy International Administration," (IEA) in 2016 for instance, reported that in the past decades, the energy global energy consumption had increased significantly [18], IEA 2016). Thus, it becomes imperative for a contemporary economy to produce sufficient energy that will meet the increasing energy demand. Nevertheless, it should be noted that unclean energy technologies are detrimental to the environment [18], owing to greenhouse gas emissions.

In the literature, two main approaches were identified for addressing the global emission issue. According to Dinda and Coondoo [33], the first is the proposition of a reduction in the energy consumption, which implies that there should be a reduction in the revenue growth of developed countries, while there should be expansion control in the developing countries. Differently from this, the "Environmental Kuznet Curve" (EKC) theory was proposed in the second approach that as per capita income increases, environmental degradation and pollution increases at the beginning stage of economic growth. But, at a certain stage of income, economic growth goes down along with the decrease in the environmental degradation and pollution [80]. However, the proposition has been criticized by many scholars $[37,46,96]$. The global attentions have been on the environmental degradation, which thus makes it imperative for every country to work towards mitigating the climate change. Several studies have been conducted on the determinants of carbon emissions, such as trade openness, population growth, and urbanization. Recently, some studies have suggested that among the significant factors to carbon emission are foreign direct investments (Kocak and Sargunesi 2018; [63], and financial development [51] which Shahbaz et al. [89] and Tamazian et al. [100] opined that their omission could results to an erroneous empirical finding.

Moreover, in reference to York and Light [110] who described asymmetry as a kind of irreversible causal process in which "an outcome generated by a given cause cannot be reversed by simply eliminating the cause of turning back the cause to its earlier condition". This idea of asymmetry corroborates some studies in environmental economics that opined that projections of future greenhouse gas emissions based on linear relationship (symmetric) models could, to some extent, return some inaccurate results [92, 93]. Even though studies abound on the determinant of carbon emission, the investigation of energy consumption, economic growth, financial development, and foreign direct investment have not been exhaustively investigated, especially in the context of Nigeria. It is against this backdrop that this study attempts to investigate the intensity effect of those macroeconomic variables on carbon emission in Nigeria using the symmetric and asymmetric approach. In order to address the aim of this study, a long annual data spanned from 1981 to 2016 was utilized, and employed the use of linear ARDL and performed the same model with the "Non-linear Autoregressive Distributed Lag (NARDL)" techniques [95, 99]. Thus, the findings of this study will provide deeper insight for Nigeria policymakers to understand the impact of energy consumption, economic growth, financial development, and foreign direct investment on Nigeria's environmental sustainability.

The remainder of the study is structured as follows: the next section presents the literature review, while the data and methods are presented in Sect. 3. The empirical findings and discussion are presented in Sect. 4, while the conclusion and policy implication rounded up the paper in Sect. 5. 


\section{Literature review}

The relationships between energy consumption, economic growth, financial development, foreign direct investment, and carbon emissions have been examined in the literature from different perspectives and achieved different results. For instance, it was proposed in the study of Robledo and Olivares [86] that in the long-run for "CIVETS (Indonesia, Vietnam, Egypt, Turkey, and South Africa)", economic growth and energy consumption determines the increase in carbon emissions. Similarly, a yearly data of 11 "Commonwealth of Independent States (CIS)" countries from 1992 to 2004 was utilized in the study of Apergis and Payne [17] to investigate the relationship between energy consumption, economic growth and $\mathrm{CO}_{2}$ emission. The results revealed that large number of the country in the panel rely on several energy sources which is a source of environmental pollution. An investigation into the nexus among energy consumption, economic growth, and environmental degradation was conducted by Farhani and Rejeb [38] in the 15 "Middle East and North Africa (MENA)" countries, where the study found a relationship between energy consumption, economic growth, and environmental degradation. The study posited that the environmental degradation could be affected by energy consumption without any feedback for energy consumption in the short-run. This finding was corroborated by Yazdi and Khanalizadeh (2017).

Besides, Dritsaki and Dritsaki [34] conducted a study to examine the causal relationship between energy consumption and environmental degradation in the Southern Europe for the period from 1960 to 2009. The study employed "fully modified ordinary least square (FMOLS)" and "dynamic ordinary least square (DOLS)" to reveal that an increase in energy consumption can lead to an increase in carbon emissions in the countries under study. Meanwhile, the study of Al-Mulali et al. [12] investigated the energy consumption-carbon emission link with the inclusion of urbanization in different regions of the world and found that the $\mathrm{CO}_{2}$ emissions was affected positively by energy consumption in some countries, while some showed a mixed result. In addition, the study found that the result for low-income countries revealed no impact of energy consumption on $\mathrm{CO}_{2}$ emissions. The dynamic effect of energy consumption on Malaysia's carbon emissions was explored in the study of Begum et al. [23]. The study rejected the EKC hypothesis and posited that a long-run positive impact of energy consumption on carbon emissions exists. In the study of Javid and Sharif [50], a bi-directional relationship between energy consumption and carbon emission was established for Pakistan. A similar result was established by Ahmad et al. [7] for India. In contrast, the study of Waheed et al. [102] established a significant negative influence of renewable energy consumption on carbon emissions in Pakistan. The study concluded that increase renewable energy consumption would result to a reduction in the carbon emission. This finding contradicts the study of 65 that found a unidirectional relationship from energy consumption to carbon emission. It concluded that an increase in energy consumption in Pakistan would increase carbon emission. A recent study by Islam et al. [48] investigates the relationship between energy consumption, economic growth, and $\mathrm{CO}_{2}$ emissions in selected Southeast Asian countries. The result revealed that energy consumption and economic growth increase $\mathrm{CO}_{2}$ emissions. Meanwhile, some recent studies tilted their studies towards the investigation of energy types and the implication on carbon emission. The studies supported the arguments that renewable energy and non-renewable energy can be detrimental to the environment $[15,52,54,74]$. Another recent study for a single country from Shabestari [88] and Sarwar et al. [87] for Sweden and China respectively confirmed a positive relationship between energy consumption and carbon emission.

The studies on the relationship between economic growth and carbon emission in the literature have been mixed. While some studies presented a unidirectional relationship between economic growth and carbon emission [7, 10, 16, 23, 44, 61, 64], Saboori et al. 2012; [91, 103, 107],), some established a bidirectional relationship [8, 22, 45],Jebli and Youssef 2017; [65, 74, 85, 88]. Though, few of them concludes in their studies that no causality exists between economic growth and carbon emission (Jardon et al. 2017; $[87,109]$. Besides the establishment of the significant relationship between economic growth and carbon emission, the study of Xu and Lin [107] that investigates economic growth and carbon emission is China revealed the presence of a $\mathrm{U}$-shaped relationship between industrialization and $\mathrm{CO}_{2}$ emission, and submitted that the two significant aspect of economic growth were found to significantly effects the $\mathrm{CO}_{2}$ emission. Abid [1] established a monotonically relationship between economic growth and carbon emission in Tunisia. The EKC hypothesis was rejected in the study, and the study revealed a unidirectional causality from formal economic growth to carbon emission. In contrast, bidirectional causality between $\mathrm{CO}_{2}$ emissions and economic growth was established. Thus, the study concluded that the informal economy advances at the detriment of the environment. Similarly, the study of Mikayilov et al. [64] rejected EKC hypothesis for Azerbaijan and suggested but established a long-run positive and significant influence of economic growth on carbon 
emissions. In contrast, the EKC hypothesis was validated in Ahmad et al. [8] study.

The study of Aye and Edoja [20] highlighted four theoretical views on the influence of financial development on $\mathrm{CO}_{2}$ emission: the eco-friendly technology, the foreign direct investment, the manufacturing sector improvement, and the enhancement of consumer credit perspective. The first proposition is that financial development decreases $\mathrm{CO}_{2}$ emission when the financial markets make provision for financial assistance to the local firms so that they can acquire eco-friendly and clean technology for manufacturing purposes. This theoretical perspective corroborated the study of Yuxiang and Chen [111], who posited that the financial sector in China provides funding and technical assistance that enables the companies to adopt new and advanced technology that improves their production and at the same time decrease the $\mathrm{CO}_{2}$ emissions. The study of Frankel and Rose (2012) also opined that "financial market can effectively allocate financial resources to the domestic firms to enable them purchase environment-friendly technology". Some studies observed that there would be an increase in carbon emission on one hand if financial development generates demands for energy by using technologies $[35,71,106]$. On the other hand, credit facilities and investment channels provided by financial system and international trade may give room for an enabling environment for research and development of low-carbon energy sources if financial development is incorporated into eco-friendly policies and regulations $[27,90]$. This is an indication that financial development could mitigate environmental degradation by reducing carbon emission in the economy [66].

From the empirical perspective, studies abound on the relationship between financial development and $\mathrm{CO}_{2}$ emissions, for instance, Shahbaz et al. [89] the nexus among economic growth, energy consumption, financial development, trade openness, and carbon emissions in Indonesia using ARDL, VECM, and the innovative accounting approach to Granger causality. The study's findings indicate that while in the oil-abundant economy, energy consumption and economic growth drive carbon emissions, financial development and trade openness contribute to reducing $\mathrm{CO}_{2}$ emissions. The study of Sy et al. [97] investigated the interrelationship between financial development, $\mathrm{CO}_{2}$ emissions, and economic growth in 40 European countries suing OLS techniques. The study found, among others the existence of neutrality hypothesis between financial development and $\mathrm{CO}_{2}$ emissions. Moreover, the relationship between financial development and carbon emissions was examined by Charfeddine and
Khediri [28] based on the EKC hypothesis for "United Arab Emirate" (UAE). The study revealed an inverted U-shaped relationship between financial development and carbon emissions, which indicates that carbon emissions increase as financial sector develops and then decline when the financial sectors gets to maturity stage and generate efficiency in the allocation of resources. Similar study was conducted in Bangladesh by Alom et al. [13], and the study found a positive impact of financial development on $\mathrm{CO}_{2}$ emissions. Kong and Wei [58] investigate the nexus between financial development and $\mathrm{CO}_{2}$ emission using a panel data that comprises of China's 30 provinces. The study established that a low financial development contributes to the reduction of $\mathrm{CO}_{2}$, while a higher levels of financial development results to an increase in $\mathrm{CO}_{2}$ emissions. The effect of financial development on carbon emissions in 129 countries was explored by Al-Mulali et al. [11]. The result revealed that financial development in the short-and long-run improves environmental quality owing to its negative impact on carbon emissions. The study of Nasreen et al. [72] was tilted towards the determination of effect of financial stability on the $\mathrm{CO}_{2}$ emissions. The result confirmed the contribution of financial stability to the reduction of environmental degradation. A recent study by Xu et al. [106] examined the nexus between financial development and carbon emissions in Saudi Arabia using the "Autoregressive Distributed Lags" (ARDL) and "Vector Error Correction Model" (VECM). The study revealed a significant and positive relationship and bidirectional causality between financial development and carbon emissions.

Some studies extended their analysis by applying the asymmetric techniques to examine the relationship between financial development and carbon emissions. The NARDL technique was employed by Ahmad et al. [6] to explore the impact of positive and negative shock in financial development on carbon emissions in China. The study showed a positive shock in financial development influences carbon emissions the more in the long-run than the negative shock in financial development. Another study by Ibrahiem [47] established a significant impact of technological innovation and financial sector development on Egypt's carbon emissions. Meanwhile, similar study by Karasoy [53] in Turkey found an insignificant short-run and long-run asymmetric effect of financial development on carbon emissions. However, Geok (2020) concluded in his study that the impact of financial development on carbon emissions varies based on the econometric techniques employed by studies, countries, or region and the time covered in the study. 
Moreover, literature suggested there is existence of a relationship between foreign direct investment and carbon emissions $[2,14,56,63]$. The study of Aminu [14] examined the influence of "dirty" FDI in host countries on the carbon emissions, using the disaggregated FDI data of eleven OECD countries, and revealed that "dirty" FDI outflow is positively associated with their environmental policy. The relationship of FDI with carbon emission was explored by Acharyya [2] within India context. The study revealed that the long-run growth effect of FDI inflow on carbon emissions is quite large. Meanwhile, Yanchun [108] conducted a similar study in China found a significant negative impact of FDI on carbon emissions. Kim [56] investigates the relationship between carbon emissions, FDI, and energy consumption using a data of "Asian Newly Industrialized Countries (ANICS)". The study employed VECM and found an indirect causality from FDI to carbon emissions in the short-run. A recent study by Maku et al. [63] explored the impact of FDI on carbon emissions in Nigeria using yearly data spanning from 1980 to 2014. The cointegration technique was applied for the estimation, and the result revealed an insignificant impact of FDI on carbon emission in Nigeria.

Form the above discussions; it is apparent that different authors have examined the relationships between energy consumption, economic growth, financial development, foreign direct investment, and carbon emissions within a different context. However, in Nigeria's background, the study that investigates the effect of these variables on environmental sustainability in Nigeria is scant in the literature, especially the asymmetric effect of these variables on carbon emission in Nigeria. Thus, the aim of this study to fill the existing gaps and contributes to the literature.

\section{Data and model specification}

\subsection{Data description}

In this empirical analysis, the indicators deployed are $\mathrm{CO}_{2}$ emissions $\left(\mathrm{CO}_{2}\right)$, financial development (FD), foreign direct investment (FDI), GDP growth ( $\mathrm{Y}$ ) and energy usage (EN). The indicators comprise of annual data stretching between 1981 and 2016. In this empirical investigation, financial development, $\mathrm{CO}_{2}$ emissions, energy usage are sourced from the Word Development Indicators (WDI 2020), while GDP growth data was gathered from Central Bank of Nigeria database. All variables were transformed into their natural logarithm. This was done to the series conform to normality [21,94]. Table 1 demonstrates a
Table 1 Descriptive Statistics

\begin{tabular}{llllll}
\hline Indicators & $\mathrm{CO}_{2}$ & $\mathrm{FDI}$ & $\mathrm{FD}$ & $\mathrm{EN}$ & $\mathrm{Y}$ \\
\hline Mean & 0.624598 & 1.619157 & 9.025943 & 719.6741 & 1252.255 \\
Median & 0.681598 & 1.412202 & 8.102352 & 714.2694 & 838.9531 \\
Maximum & 0.874309 & 5.790847 & 19.62560 & 798.6302 & 3222.694 \\
Minimum & 0.312014 & 0.257422 & 4.957522 & 671.9069 & 270.2240 \\
Std. Dev & 0.181119 & 1.259798 & 3.629972 & 36.66954 & 898.1449 \\
Skewness & -0.469022 & 1.640054 & 1.340796 & 0.476919 & 0.733857 \\
Kurtosis & 1.835349 & 5.684260 & 4.236122 & 1.998599 & 2.114551 \\
Jarque- & 3.354512 & 26.94655 & 13.07839 & 2.868918 & 4.407307 \\
Bera & & & & & \\
Probability & 0.186886 & 0.000001 & 0.001446 & 0.238244 & 0.110399 \\
Observa- & 36 & 36 & 36 & 36 & 36 \\
tions & & & & & \\
Correlation & matrix & & & & \\
CO & 1 & -0.3657 & 0.1013 & 0.24155 & 0.4788 \\
FDI & -0.3657 & 1 & 0.1505 & 0.10020 & -0.1915 \\
FD & 0.1013 & 0.1505 & 1 & 0.63466 & 0.6584 \\
EN & 0.2415 & 0.1002 & 0.6346 & 1 & 0.7378 \\
Y & 0.4788 & -0.1915 & 0.65840 & 0.73789 & 1 \\
\hline
\end{tabular}

Source Authors Collation with Eviews-11

summary of indicators and the correlation amongst them. The table depicts that FDI inflows and financial development are more volatile compared to other indicators. A $\mathrm{CO}_{2}$ emission has the lowest volatility, suggesting that the $\mathrm{CO}_{2}$ emission was steady from 1981 to 2016 in Nigeria. The results display the asymmetric distribution, as indicated by the skewness. As for the distribution of the series, we cannot support the bell shape. For a normal distribution, the value of kurtosis must be less than 3 . Premised on this threshold, $\mathrm{CO}_{2}$ emissions, energy consumption, and growth demonstrates normal distribution, while FDI inflows and financial development do not portray normal distribution. Additionally, the correlation matrix illustrates the strength and sign of correlation amongst the indications in this empirical analysis. The findings from the correlation matrix reveals that $\mathrm{FDI}$ and $\mathrm{CO}_{2}$ and $\mathrm{FDI}$ and $\mathrm{Y}$ have negative correlation with remaining variables having positive correlations.

\subsection{Model specification}

Prior research on the interconnection among $\mathrm{CO}_{2}$ emissions, financial development, GDP growth, energy use and FDI inflows is often explored by deploying the standard time-series methods of the ARDL co-integration. The ARDL is accompanied by "Error Correction Model"ECM and 
causality approaches. Moreover, econometric approaches enable us to determine the presence of long-term interrelationships, combined with short-term interactions. However, they are not adequate to attain feasible asymmetries between metrics. The research carried out by Pesaran et al. [81] advanced the ARDL method based on a further analysis by Pesaran et al. [83] asymmetric modification of the non-linear ARDL co-integration methodology (NARDL) to obtain long-term and short-term asymmetries in the focus parameters. The modeling methodology is utilized to ascertain the asymmetric impact of FDI inflows and financial development on $\mathrm{CO}_{2}$ in Nigeria. Recently, studies have utilized the NARDL to examine the interaction between $\mathrm{CO}_{2}$ emissions and its determinants in various countries [6, $26,52,54,68,69,97]$. The linkages between $\mathrm{CO}_{2}$ emissions and enegy usage, real growth, financial development, FDI inflows is illustrated in prior to formulating of the NARDL model,

The study economic function, economic model and econometric model is portrayed in Eq. 1, 2 and 3 correspondingly.

$$
\mathrm{CO}_{2}=f\left(F D I^{+} F D I^{-}, F D^{+} F D^{-}, E N, Y\right)
$$

$$
\mathrm{CO}_{2 t}=\theta_{0}+\theta_{1}^{+} F I_{t}^{+}+\theta_{2}^{-} F D I_{t}^{-}+\theta_{3}^{+} F D_{t}^{+}+\theta_{4}^{-} F D_{t}^{-}+\theta_{5} E N_{t}+\theta_{6} Y_{t}
$$

$$
\begin{aligned}
C_{2 t}= & \theta_{0}+\theta_{1}^{+} F D I_{t}^{+}+\theta_{2}^{-} F D I_{t}^{-}+\theta_{3}^{+} F D_{t}^{+}+\theta_{4}^{-} I N F_{t}^{-} \\
& +\theta_{5} E N_{t}+\theta_{6} Y_{t}+\varepsilon_{t}
\end{aligned}
$$

where $\mathrm{CO}_{2}$ portrays the $\mathrm{CO}_{2}$ emissions, $\mathrm{FD}$ and $\mathrm{FDI}$ illustrates financial development and FDI inflows, EN and $Y$ depicts energy use and GDP growth, and $\theta=\theta_{1}^{+}, \theta_{2}^{-}, \theta_{3}^{+}, \theta_{4}^{-}, \theta_{5}, \theta_{6}$, illustrates the coefficients. $F D I_{t}=F D I_{0}+F D I_{t}^{+}+F D I_{t}^{-}$, where $F D I_{t}^{+}+F D I_{t}^{-}$are the partial sum process of variation which are positive and negative in FDI. Also, $F D_{t}=F D_{0}+F D_{t}^{+}+F D_{t}^{-}$, where $F D_{t}^{+}+F D_{t}^{-}$ are the partial sum process of variation which are positive and negative in $\mathrm{FD}$

$$
\begin{aligned}
F D I_{t}^{+} & =\sum_{j=1}^{s} \Delta F D I_{j}^{+}=\sum_{k=1}^{s} \max \left(\Delta F D I_{j}, 0\right), F D I_{t}^{-} \\
& =\sum_{k=1}^{s} \min \left(\Delta F D I_{j}, 0\right)+\varepsilon_{t} \\
F D_{t}^{+} & =\sum_{j=1}^{s} \Delta F D_{j}^{+}=\sum_{k=1}^{s} \max \left(\Delta F D_{j,} 0\right), F D_{t}^{-}=\sum_{k=1}^{s} \min \left(\Delta F D_{j}, 0\right)+\varepsilon_{t}
\end{aligned}
$$

In the non-linear sense of Schorderet [98], the above equations focused on the decomposition of the partial principle of asymmetric co-integration was utilized to examine the association between unemployment and economic growth and to ascertain the non-linear linkage between unemployment and economic growth. For this study, Eq. (3) may be modified as described by Pesaran et al. [81] and 82 perspectives of the ARDL,

$$
\begin{aligned}
\Delta C O_{2 t}= & \delta_{0}+\theta_{1} C O_{2 t-1}+\theta_{2}^{+} F D I_{t-1}^{+}+\theta_{3}^{-} F D I_{t-1}^{-}+\theta_{4}^{+} F D_{t-1}^{+} \\
& +\theta_{5}^{-} F D_{t-1}^{-}+\theta_{6} E N_{t-1}+\theta_{7} Y_{t-1}+\sum_{i=1}^{p} \emptyset_{i} \Delta C O_{2 t-1} \\
& +\sum_{i=0}^{t}\left(\pi_{i}^{+} \Delta F D I_{t-1}^{+}+\pi_{i}^{-} \Delta F D I_{t-1}^{-}\right)+\sum_{i=0}^{K}\left(\tau_{i}^{+} \Delta F D_{t-1}^{+}\right. \\
& \left.+\tau_{i}^{-} \Delta F D_{t-1}^{-}\right) \sum_{i=1}^{V} \varphi_{1} \Delta E N_{t-1}+\sum_{i=1}^{c} \varphi_{2} \Delta Y_{t-1}+\varepsilon_{t}
\end{aligned}
$$

Where the lag orders are $t, k, v$ and $c$. The implicit issue of co-integration emerges in the measured Eq. 3 in such a way that it cannot offer a clear interpretation of the determined asymmetric coefficients. As a result, a limitation is inserted on Eq. 3 coefficients, such as $\theta_{1}^{+}=\frac{-\theta_{2}^{+}}{\theta_{1}}$ and $\theta_{2}^{-}=\frac{-\theta_{3}^{-}}{\theta_{1}}, \theta_{3}^{+}=\frac{-\theta_{4}^{+}}{\theta_{1}}$ and $\theta_{4}^{-}=\frac{-\theta_{5}^{-}}{\theta_{1}}$ as proposed by 42 and 62 . $\sum_{i=0}^{t} \pi_{i}^{+}$calculates the potential short-term effect of an increase in FDI inflows and financial development on $\mathrm{CO}_{2}$ emissions, whereas $\sum_{i=0}^{t} \pi_{i}^{-}$calculates the short-term impact of a reduction of FDI inflows and financial development on $\mathrm{CO}_{2}$ emissions. Consequently, the short-term asymmetrical effects of FDI inflows, and financial development on $\mathrm{CO}_{2}$ emissions, along with long-term asymmetrical interconnection, is also described in this framework. The Error Correction Model (ECM) for Eq. 6 is shown as follows;

$$
\begin{aligned}
\Delta C O_{2 t}= & \sum_{i=1}^{p} \phi_{i} \Delta C O_{2 t-1}+\sum_{i=0}^{t}\left(K_{i}^{+} \Delta F D I_{t-1}^{+}+K_{i}^{-} F D I_{t-1}^{-}\right) \\
& +\sum_{i=0}^{k}\left(C_{i}^{+} \Delta F D_{t-1}^{+}+C_{i}^{-} \Delta F D_{t-1}^{-}\right)+\sum_{i=1}^{v} \varpi_{i} \Delta E N_{t-1} \\
& +\sum_{i=1}^{s} \eta_{i} \Delta Y_{t-1}+R_{i} E C T_{t-1}+\mu_{t}
\end{aligned}
$$

Where $\phi_{i}, \varpi_{i}$ and $\eta_{i}$ stand for coefficients in the short-run and $K_{i}^{+}, K_{i}^{-}$and $C_{i}^{+}, C_{i}^{-}$portrays adjustment symmetry in the short-run, whereas $R_{i}$ Specifies the coefficient of error correction term. The calculation of the NARDL methodology requires the following procedures. Firstly, the ARDL method is accurate irrespective of whether all indicators are integrated of $\mathrm{I}(0)$ or $\mathrm{I}(1)$ or $\mathrm{I}(0)$ and $\mathrm{I}(1)$. It is quite essential to implement the unit-root test to ensure that no series is integrated of I(2) since the presence of the I(2) component makes null and void the predicted F-stat for evaluating cointegration (Adebayo and Demet, 2020). To 
Table 2 ADF and PP Tests

\begin{tabular}{|c|c|c|c|c|c|c|}
\hline & \multicolumn{3}{|l|}{ ADF } & \multicolumn{3}{|l|}{ PP } \\
\hline & Level T-Pro & First-Difference T-Pro & Decision & Level T-Pro & First-Difference T-Pro & Decision \\
\hline $\mathrm{CO}_{2}$ & $-1.95(0.60)$ & $-5.98(0.00)$ & $\mathrm{I}(1)$ & $-1.95(0.60)$ & $-5.98(0.00)$ & $\mathrm{I}(1)$ \\
\hline FDI & $-3.23(0.09)$ & $-9.26(0.00)$ & $I(0) I(1)$ & $-3.07(0.12)$ & $-9.79(0.00)$ & $\mathrm{I}(1)$ \\
\hline FD & $-4.25(0.01)$ & $-5.42(0.00)$ & $I(0) I(1)$ & $-33(0.40)$ & $-10.08(0.00)$ & $\mathrm{I}(1)$ \\
\hline Y & $-1.46(0.82)$ & $-3.56(0.04)$ & $\mathrm{I}(1)$ & $-3.08(0.126)$ & $-3.56(0.048)$ & $\mathrm{I}(1)$ \\
\hline EN & $-2.80(0.20)$ & $-5.61(0.00)$ & $\mathrm{I}(1)$ & $-2.88(0.25)$ & $-5.57(0.00)$ & $\mathrm{I}(1)$ \\
\hline
\end{tabular}

Source Investigators Collation with EViews-11

Table 3 ZA Test

\begin{tabular}{llllll}
\hline & Level T-Pro & Break & First-Difference T-Pro & Break & Decision \\
\hline $\mathrm{CO}_{2}$ & $-3.42(0.20)$ & 1994 & $-6.77(0.00)$ & 2000 & $\mathrm{I}(1)$ \\
$\mathrm{FDI}$ & $-5.55(0.00)$ & 1995 & $-9.77(0.00)$ & 1995 & $\mathrm{I}(0) \mathrm{I}(1)$ \\
$\mathrm{FD}$ & $-7.54(0.00)$ & 2007 & $-5.93(0.00)$ & 2007 & $\mathrm{I}(0) \mathrm{I}(1)$ \\
$\mathrm{Y}$ & $-3.42(0.29)$ & 1993 & $-5.60(0.00)$ & 2002 & $\mathrm{I}(1)$ \\
$\mathrm{EN}$ & $-5.64(0.00)$ & 2000 & $-6.17(0.00)$ & 2010 & $\mathrm{I}(0) \mathrm{I}(1)$ \\
\hline
\end{tabular}

Source Investigators Collation with EViews-11

eradicate this issue, the widely utilized "Augmented Dickey Fuller" (ADF) and "Phillip-Peron" (PP) unit-root tests were utilized to evaluate the integration order. Furthermore, the Zivot-Andrew unit root tests were deployed to capture the existence of a structural break. Next, Eq. 3 is calculated using the Ordinary Least Squares (OLS) standard method. The overall-to-specific approach was introduced to boost the final condition of the NARDL framework by reducing negligible lags (60). After calculating NARDL, a check for the existence of long-term interaction between the indicators in the model is performed by utilizing a bounds testing proposed by 81 and 95,98$)$. It encompasses the Wald F-test of the null hypothesis, $H_{0}: \theta_{1}=\theta_{2}=\theta_{3}^{+}=+\theta_{4}^{-}=0$ against $H_{0}: \theta_{1} \neq \theta_{2} \neq \theta_{3}^{+} \neq+\theta_{4}^{-} \neq 0$. Ultimately, with the advent of cointegration, an analysis of long and shortterm asymmetries in the interconnection between $\mathrm{CO} 2$ emissions and FDI inflows and financial development are performed and conclusions were made. Additionally, asymmetric cumulative dynamic multiplier impacts of $1 \%$ discrepancy in $F I_{t-1}^{+}$andFDI ${ }_{t-1}^{-}$and $F D_{t-1}^{+}$andFD $D_{t-1}^{-}$correspondingly were calculated in Eqs. 7 and 8;

$$
\begin{aligned}
& B_{a}^{+}=\sum_{j=0}^{a} \frac{\rho \mathrm{CO}_{2 t+j}}{\rho F D I_{t-1}^{+}}, B_{a}^{-}=\sum_{j=0}^{a} \frac{\rho C 0_{2 t+j}}{\rho F D I_{t-1}^{-}}, a=1,2 \\
& T_{a}^{+}=\sum_{j=0}^{a} \frac{\varphi C O_{2 t+j}}{\varphi F D_{t-1}^{+}}, T_{a}^{-}=\sum_{j=0}^{a} \frac{\varphi C O_{2 t+j}}{\varphi F D_{t-1}^{-}}, a=1,2
\end{aligned}
$$

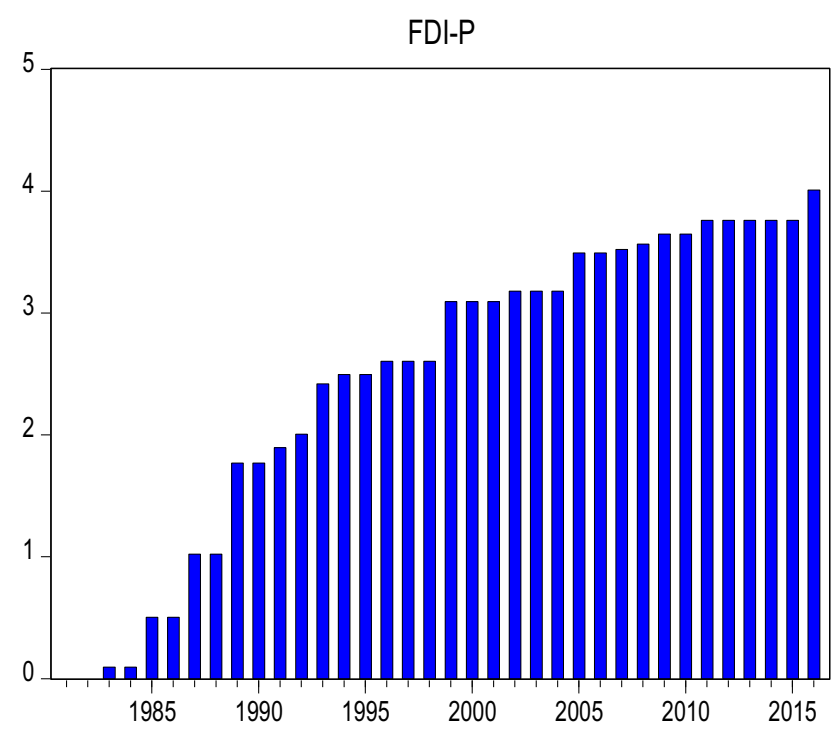

Fig. 1 FDI (+)

It is worth remembering that as a $\rightarrow \infty, B_{a}^{+} \rightarrow \theta_{1}^{+}, B_{a}^{-} \rightarrow \theta_{2}^{-}$and $\rightarrow \infty, T_{a}^{+} \rightarrow \theta_{1}^{+}, T_{a}^{-} \rightarrow \theta_{2}^{-}$.

\section{Empirical findings}

It is essential to check each variable for stationarity before conducting cointegration checks. The regression analysis will yield false findings if the data set is not stationary $(43 ; 5 ; 78)$. One requirement of the bounds testing approach is that no single indicator must be I(2), though $I(1)$ or $I(0)$ or mixed of $I(I)$ and $I(0)$ integration order is accepted. Tables 2 and 3 portray the outcomes of the unit root tests at the trend and intercept. The Schwarz Information Criterion (SIC) is used for optimum lag selection for Augmented Dickey Fuller (ADF) and Phillip Perron unit root tests. The tests signify that inflation, FDI inflows, and exchange rates have a mixed integration order, like I(1) and I(0) respectively, therefore, the 


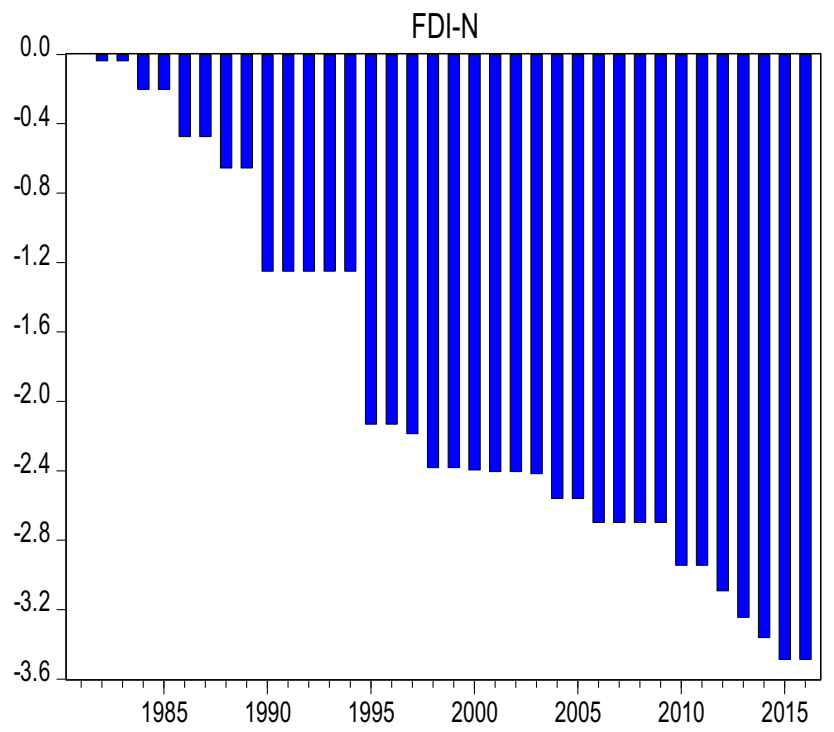

Fig. 2 FDI (-)

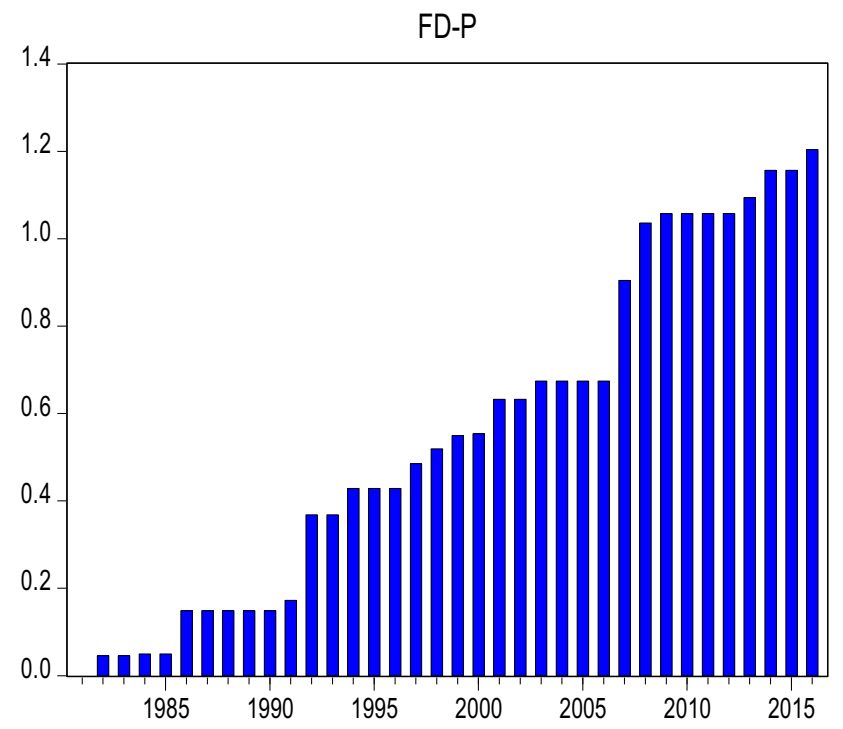

Fig. 3 FD (+)

bound test procedures are next. After unit root testing was conducted, SIC is utilized to verify the optimal lag order for the framework utilizing a vector autoregressive (VAR) method. The NARDL method starts to distinguish between negative and positive variables of the FDI inflows and financial development. Figures 1 and 2 illustrate the negative and positive components of FDI inflows while Figs. 3 and 4 denote the negative and positive parts of financial development. Table 4 demonstrates the short and long run asymmetric for financial development and FDI inflows. Results from the table

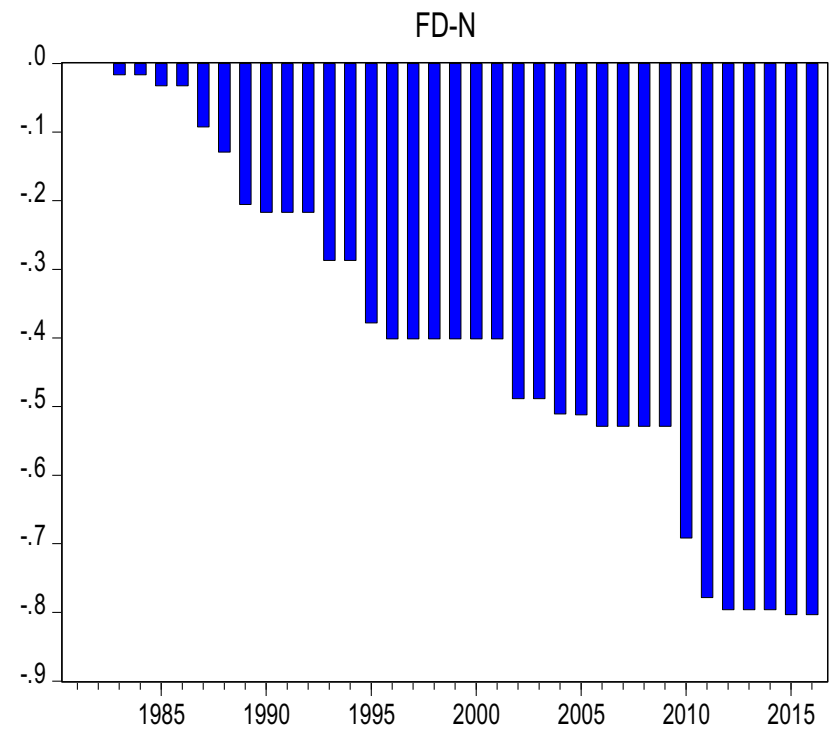

Fig. 4 FD (-)

Table 4 Long and short run asymmetric

\begin{tabular}{llll}
\hline & & F-stats & P-value \\
\hline FDI & Long-run & 7.935 & $0.058^{* * *}$ \\
& Short-run & 12.52 & $0.038^{* *}$ \\
FD & Long-run & 5.899 & $0.026^{* *}$ \\
& Short-run & 4.446 & $0.050^{* *}$
\end{tabular}

$1 \%$ and $5 \%$ significance level portrays*

${ }^{* *}$ levels correspondingly

Source Investigators Collation with EViews-11

Table 5 ARDL and NARDL Cointegration

\begin{tabular}{llllll}
\hline F-Stats & ARDL & & & NARDL \\
\cline { 2 - 2 } \cline { 5 - 6 } & $4.77^{* * *}$ & & & $4.60^{*}$ & \\
\hline Cointegration & Yes & & & Yes & \\
Significant Level & L-B I(0) & U-B I(1) & & L-B I(0) & U-B I(1) \\
$10 \%$ & 2.45 & 3.52 & & 2.12 & 3.23 \\
$5 \%$ & 2.86 & 4.01 & & 2.45 & 3.61 \\
$2.5 \%$ & 3.25 & 4.49 & & 2.75 & 3.99 \\
$1 \%$ & 3.74 & 5.06 & & 3.15 & 4.43
\end{tabular}

$1 \%$ and $5 \%$ significance level portrays*

${ }^{* *}$ levels correspondingly. L-B \& U-B illustrates the lower and upper bound correspondingly

Source Investigators Collation with EViews-11

depict evidence of asymmetric effect for FDI inflows and financial development. 


\subsection{Cointegration results}

Table 5 portrays the result of the ARDL and NARDL. The ARDL model, at a $5 \%$ significance level, the F-stat (4.77) is greater than the upper and lower bound, which portrays evidence of cointegration amongst the series deployed. Also, in the NARDL model, at a $1 \%$ significance level, the F-stat (4.60) is higher than the upper and lower bound, which portrays evidence of cointegration amongst the series deployed. The Wald tests demonstrate the importance of asymmetry for both the long term and the short term, which suggests that non-linearity and asymmetry are essential when analyzing the linkage between inflation and foreign direct investment. This observation illustrates the significance of considering asymmetry while examining the impact of FDI inflows and financial development on $\mathrm{CO} 2$ emissions. More comprehensive findings are given below.

\subsection{ARDL long-run and short-run estimate}

Bearing in mind the existence of long-run linkages between variables deployed, we explored the dynamic influence of FDI inflows, energy use, GDP growth, and financial development on Nigeria's $\mathrm{CO}_{2}$ emissions. The estimated outcomes are reported in Table 6 . Findings indicate; (i) FDI inflows exert negative and significant impact on $\mathrm{CO}_{2}$ emissions. This denotes that a $1 \%$ increase in FDI inflows

Table 6 ARDL Estimations

\begin{tabular}{llll}
\hline Long-Run Result & & & \\
\hline Dep-Var & Regressors & Coefficient & T-stats \\
\hline $\mathrm{CO}_{2}$ & FDI & -0.088 & $-1.793^{* * * *}$ \\
& FD & 0.073 & 0.426 \\
& EN & 4.294 & $2.965^{*}$ \\
& Y & 0.069 & 0.086 \\
Short-Run Result & & & \\
Dep-Var & Regressors & Coefficient & T-statistics \\
$\mathrm{CO}_{2}$ & ECM(-) & -0.348 & $-5.25^{*}$ \\
& $\mathrm{FDI}$ & -0.088 & $-2.174^{* *}$ \\
& $\mathrm{FD}$ & 0.073 & 0.533 \\
& $\mathrm{Y}$ & 0.069 & 0.123 \\
$\mathrm{R}^{2}$ & & 0.84 & \\
Adj R & & 0.83 & \\
$\chi^{2}$ Heteroscedasticity & & $1.38(0.24)$ & \\
$\chi^{2}$ Ramsey & & $0.74(0.39)$ & \\
$\chi^{2}$ Normality & & $0.02(0.98)$ & \\
$\chi^{2}$ LM & & $2.11(0.14)$ & \\
\hline
\end{tabular}

$1 \%$ and $5 \%$ and $10 \%$ significance level portrays $*{ }^{* *}$ and ${ }^{* * *}$ levels correspondingly

Source Investigators Collation with EViews-11 will decrease $\mathrm{CO}_{2}$ emissions by $0.088 \%$. Surprisingly, FDI dampens $\mathrm{CO}_{2}$ emissions. This demonstrates that the FDI aid the improvement environmental quality. It indicates that the appeal of FDI in Nigeria is perceived to be environmentally sustainable during the span of investigation. The study of 25 in Nigeria and 108 in China corroborate this finding. (ii) No significant linkage between financial development and $\mathrm{CO}_{2}$ emissions. The finding of 97 in 40 European countries correspond with this outcome. (iii) Energy consumption affects $\mathrm{CO}_{2}$ emissions positively. This denotes that a $1 \%$ increase in energy consumption will increase $\mathrm{CO}_{2}$ emissions by $4.29 \%$. This outcome corroborates with the findings of Yazdi and Shakouri (2014), Tariq et al. (2016) Etokakpan et al. (2020) and 9. (iv) No significant interaction exists between $\mathrm{CO}_{2}$ emissions and economic growth. The result aligns with prior studies (70; 30; 3). In the short term, only FDI inflow has adverse impacts on $\mathrm{CO}_{2}$ emissions. The coefficient $(-0.34)$ of the error correction model (ECM) is also significant, suggesting a faster return to equilibrium in the event of imbalance. The $R^{2}$ for the ARDL is $0.84(84 \%)$, which depicts that FDI inflows, financial development, energy usage, and GDP growth can explain $84 \%$ of the variation in $\mathrm{CO}_{2}$ emissions while the remaining $16 \%$ is attributed to error term. Also, the absence of heteroscedasticity and serial correlation was noticed in. Furthermore, residuals are normally distributed and the Ramsey test provides no misspecification in the two models. Therefore, we fail to reject the null hypothesis of the relative tests. These findings indicate that the ARDL model is reliable and consistent and the conclusion can be drawn from it. In addition, the findings from the ARDL CUSUM and CUSUMSq in Figs. $5 \mathrm{a}$ and $5 \mathrm{~b}$ respectively illustrates that the model is stable.

\subsection{Robustness check}

The study also checks the robustness of the ARDL longrun estimate by deploying the FMOLS and DOLS. Tables 7 demonstrate the result of the FMOLS and DOLS. The result of the FMOLS and DOLS corroborates with the finding of the ARDL long-run estimation.

\subsection{NARDL long-run and short-run estimate}

Table 8 demonstrates the result of the NARDL results. In the long run, positive FDI inflows shock has a detrimental and significant impact on $\mathrm{CO}_{2}$ emissions $(-0.75)$, suggesting that any positive FDI inflows shock hinders $\mathrm{CO}_{2}$ emissions in Nigeria. Negative FDI inflows shock has an adverse and significant impact on $\mathrm{CO}_{2}$ emissions (-0164), suggesting that any negative shock in FDI inflows impede $\mathrm{CO}_{2}$ emissions. In regards to financial development, positive financial development shock has an adverse and 

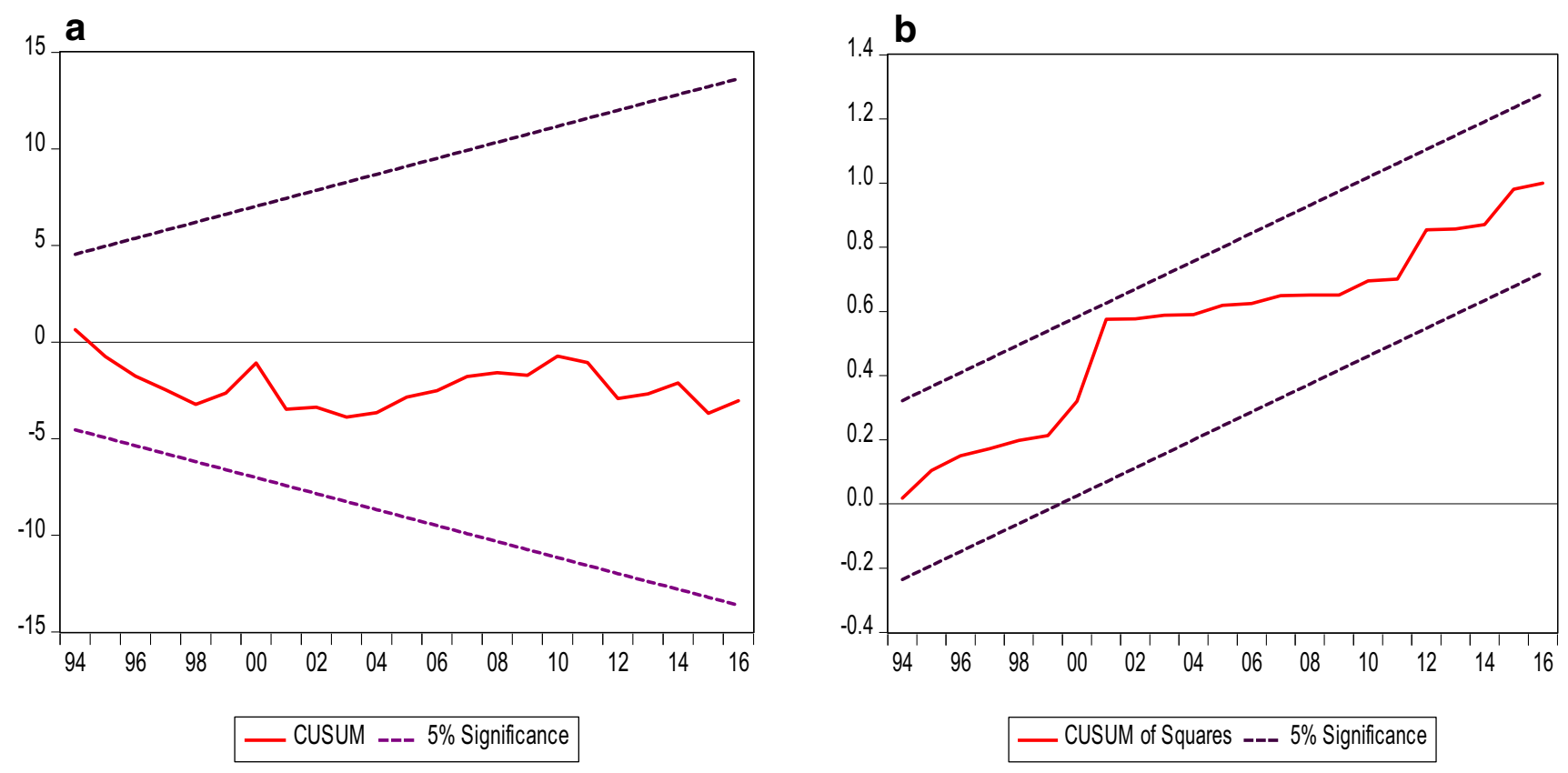

Fig. 5 a. ARDL CUSUM b. ARDL CUSUM Sq

Table 7 Robustness Check

\begin{tabular}{|c|c|c|c|c|c|}
\hline \multicolumn{6}{|c|}{ Long-Run Result } \\
\hline \multirow[b]{2}{*}{$\begin{array}{l}\text { Depend- } \\
\text { ent Vari- } \\
\text { able }\end{array}$} & \multirow[b]{2}{*}{$\begin{array}{l}\text { Regres- } \\
\text { sors }\end{array}$} & \multicolumn{2}{|l|}{ FMOLS } & \multicolumn{2}{|l|}{ DOLS } \\
\hline & & $\begin{array}{l}\text { Coeffi- } \\
\text { cient }\end{array}$ & T-stats & $\begin{array}{l}\text { Coeffi- } \\
\text { cient }\end{array}$ & T-stats \\
\hline \multirow[t]{4}{*}{$\mathrm{CO}_{2}$} & FDI & -0.086 & $-2.882^{*}$ & -0.088 & $-2.334^{* *}$ \\
\hline & FD & 0.064 & 0.628 & 0.091 & 0.543 \\
\hline & EN & 4.34 & $4.92^{*}$ & 4.294 & $3.860^{*}$ \\
\hline & $\mathrm{Y}$ & 0.168 & 0.287 & 0.069 & 0.112 \\
\hline $\mathrm{R}^{2}$ & & 0.83 & & 0.84 & \\
\hline Adj $R^{2}$ & & 0.82 & & 0.83 & \\
\hline
\end{tabular}

$1 \%, 5 \%$ and $10 \%$ significance level portrays*

${ }^{* *}$ and ${ }^{* * *}$ levels correspondingly

Source Investigators Collation with EViews-11

significant impact on $\mathrm{CO}_{2}$ emissions (-3.15), signifying that any positive financial development shock deters $\mathrm{CO}_{2}$ emissions. Negative financial development shock has a positive and insignificant impact on $\mathrm{CO}_{2}$ emissions. Furthermore, energy usage has a positive linkage with $\mathrm{CO}_{2}$ emissions. Additionally, insignificant link exists between GDP growth and $\mathrm{CO}_{2}$ emissions. In the short-run, positive FDI inflows shock has a detrimental and significant impact on $\mathrm{CO}_{2}$ emissions (-0.418), suggesting that any positive $\mathrm{FDI}$ inflows shock reduces $\mathrm{CO}_{2}$ emissions. Negative FDI inflows shock has a positive and significant impact on $\mathrm{CO}_{2}$ emissions (1.041), suggesting that any negative

Table 8 NARDL Estimations

\begin{tabular}{|c|c|c|c|}
\hline \multicolumn{4}{|l|}{ Long-Run Result } \\
\hline Dep-Var & Regressors & Coefficient & T-stats \\
\hline \multirow[t]{6}{*}{$\mathrm{CO}_{2}$} & FDI-P & -0.754453 & $-5.113^{*}$ \\
\hline & FDI-N & -1.640560 & $-4.616^{*}$ \\
\hline & FD-P & -3.158987 & $-3.034^{* *}$ \\
\hline & FD-N & 0.674240 & 1.477 \\
\hline & EN & 15.16058 & $6.802^{*}$ \\
\hline & $\mathrm{Y}$ & 3.352839 & 1.479 \\
\hline \multicolumn{4}{|l|}{ Short-Run Result } \\
\hline Dep-Var & Regressors & Coefficient & T-statistics \\
\hline \multirow[t]{7}{*}{$\mathrm{CO}_{2}$} & ECM(-) & -0.418 & $-5.258^{*}$ \\
\hline & FDI-P & -0.316 & $-3.496^{* *}$ \\
\hline & FDI-N & 1.041 & $3.755^{* *}$ \\
\hline & FD-P & 2.673 & $2.986^{* *}$ \\
\hline & FD-N & -2.875 & $-3.609 * *$ \\
\hline & EN & -7.745 & $-4.903^{*}$ \\
\hline & $\mathrm{Y}$ & 3.205 & 1.550 \\
\hline $\mathrm{R}^{2}$ & & 0.98 & \\
\hline $\operatorname{Adj} R^{2}$ & & 0.97 & \\
\hline$\chi^{2}$ Heteroscedasticity & & $0.93(0.54)$ & \\
\hline$\chi^{2}$ Ramsey & & $1.36(0.10)$ & \\
\hline$\chi^{2}$ Normality & & $0.67(0.71)$ & \\
\hline$\chi^{2} L M$ & & $2.63(0.10)$ & \\
\hline
\end{tabular}

$1 \%, 5 \%$ and $10 \%$ significance level portrays*

${ }^{* *}$ and ${ }^{* * *}$ levels correspondingly

Source Investigators Collation with EViews-11 


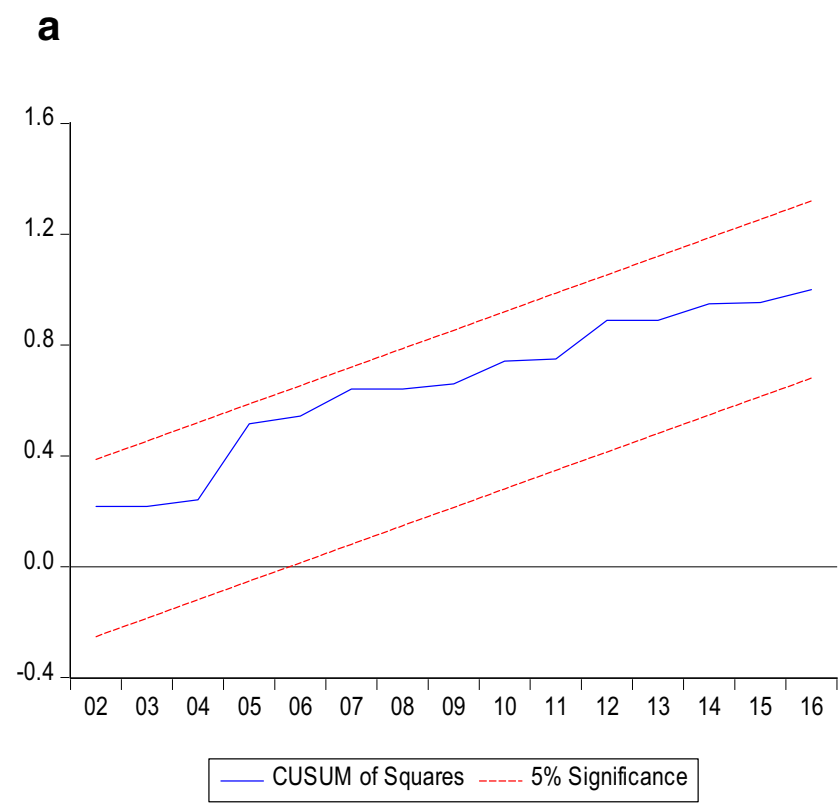

b

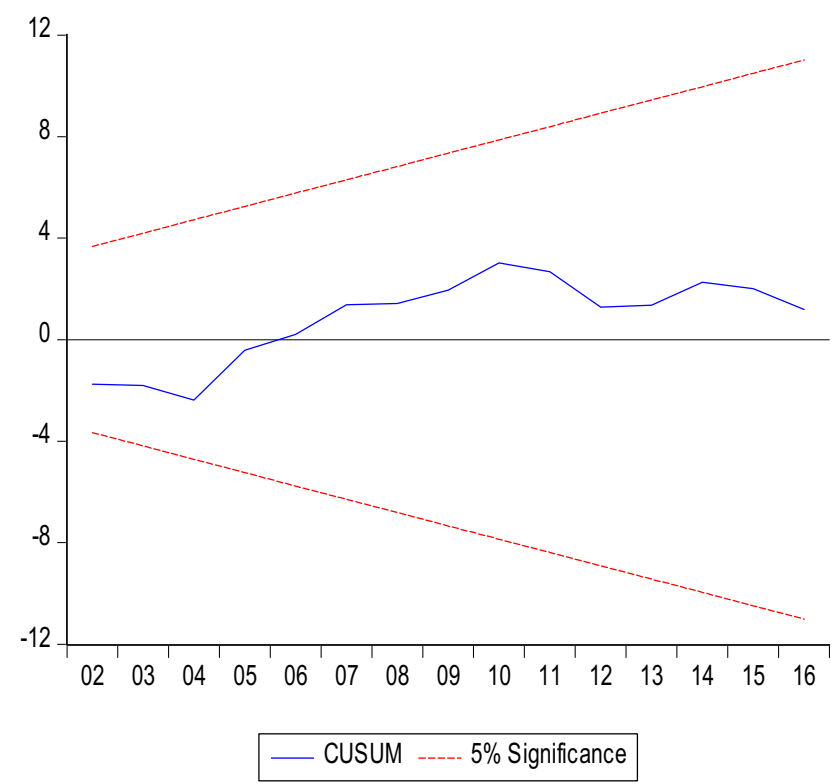

Fig. 6 a. NARDL CUSUM b. NARDL CUSUM Sq

shock in FDI inflows boost $\mathrm{CO}_{2}$ emissions. In regards to financial development, positive financial development shock has a positive and significant impact on $\mathrm{CO}_{2}$ emissions (2.673), signifying that any positive financial development shock improves $\mathrm{CO}_{2}$ emissions. Negative financial development shock has an adverse and significant impact

on $\mathrm{CO}_{2}$ emissions (-2.875). Furthermore, energy usage has a positive linkage with $\mathrm{CO}_{2}$ emissions. Additionally, no significant interaction was found between $\mathrm{CO}_{2}$ emissions and GDP growth. The $\mathrm{R}^{2}$ for the ARDL is 0.98 (98\%) which depicts that FDI inflows, financial development, energy usage, and GDP growth can explain $98 \%$ of the variation
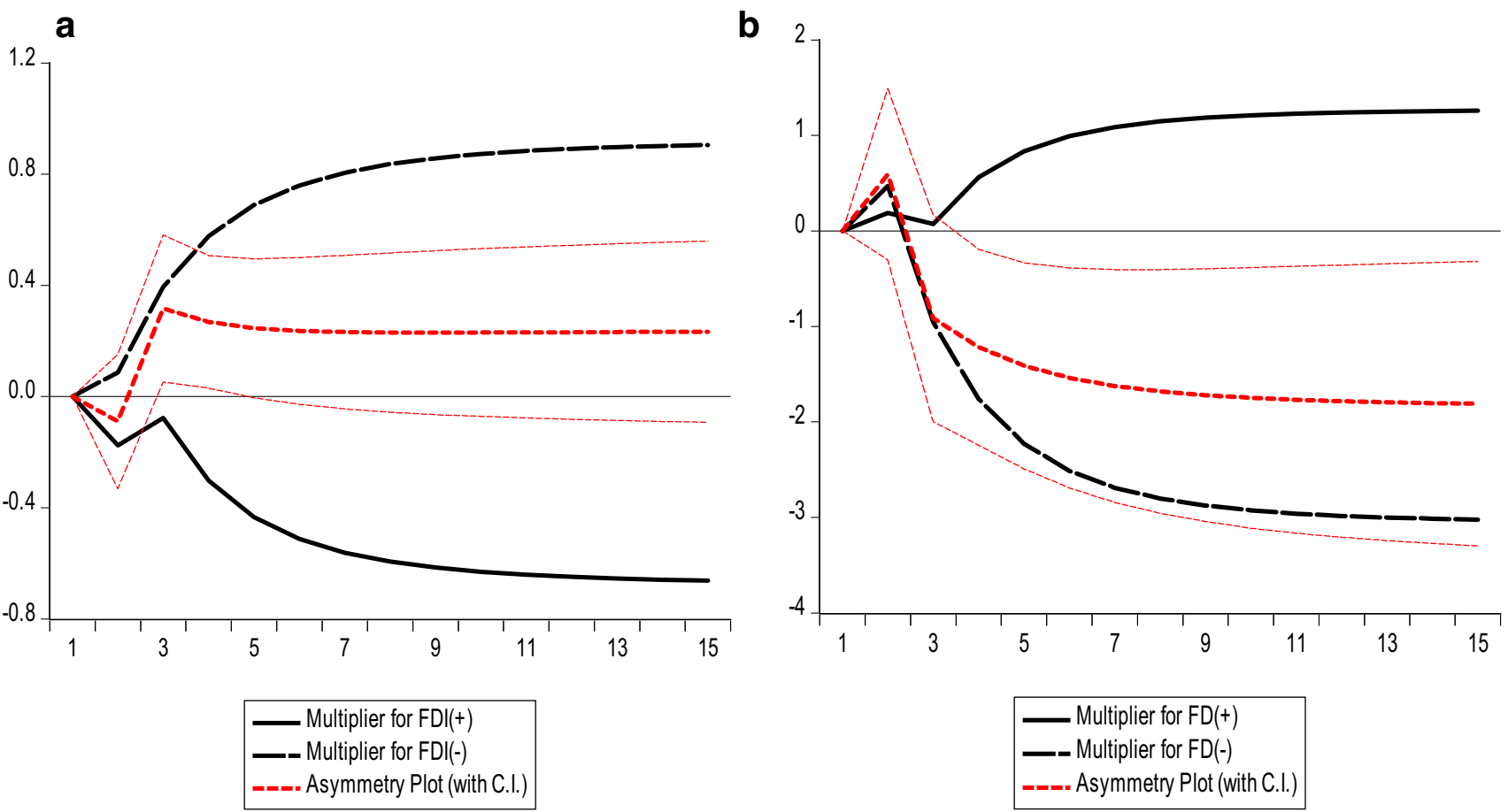

Fig. 7 a. Dynamic multiplier b. Dynamic multiplier Source Authors Collation with Eviews-11 
in $\mathrm{CO}_{2}$ emissions while the remaining $2 \%$ is attributed to error term. Also, the absence of heteroscedasticity and serial correlation was noticed in. Furthermore, residuals are normally distributed and the Ramsey test provides no misspecification in the two models. These findings indicate that the NARDL model is reliable and consistent and the conclusion can be drawn from it. In addition, the findings from the NARDL CUSUM and CUSUMSq in Figs. $6 a, b$ respectively illustrates that the model is stable.

\subsection{Dynamic multiplier}

Positive and negative shift curves provide signs of asymmetrical modification of $\mathrm{CO}_{2}$ emissions to negative and positive FDI inflows and financial development shocks over an established period. Figure 7a shows that positive FDI inflows shocks have a long-term negative impact on $\mathrm{CO}_{2}$ emissions. In contrast, negative shock in FDI inflows has a long-term positive impact on $\mathrm{CO}_{2}$ emissions. Furthermore, equilibrium is attained in the long-run in the 11 th period. Figure $7 \mathrm{~b}$ depicts that positive FD inflows shocks have a long-term positive impact on $\mathrm{CO}_{2}$ emissions, while negative shock in FD inflows has a long-term negative impact on $\mathrm{CO}_{2}$ emissions. Furthermore, equilibrium is attained in the long-run in the 10th period.

\section{Conclusion}

Our study investigates the impact of financial development, and foreign direct investment together with energy consumption, and economic growth on carbon emissions $\left(\mathrm{CO}_{2}\right)$ in Nigeria over the period 1981-2016. The study employed the linear ARDL techniques for the estimation, and to explore the asymmetric effect of financial development, and foreign direct investment impact on $\mathrm{CO}_{2}$, the non-linear ARDL techniques was employed. The findings for the linear (symmetric) effect shows that foreign direct investment (FDI), and energy consumption have a long-run relationship with $\mathrm{CO}_{2}$ in Nigeria, while only FDI has a short-run linear relationship with $\mathrm{CO}_{2}$. Interestingly, the asymmetric effects of positive and negative shocks in financial development are significantly different, while that of FDI are not significantly different. The positive change in financial development reduces carbon emissions, while negative shock shows no significant relationship. As for the FDI, the positive and negative shocks reduce the carbon emissions in Nigeria.

It is apparent from this study outcome that the policy makers in Nigeria are having challenges of balancing the achievement of high level of financial development, and the improvement of environmental quality simultaneously, in which if the country failed to develop the financial sector, it could result to massive degradation of the environment owing to its effect on triggering more carbon emissions. Thus, this study encourages the policy makers in Nigeria to implement credit policies that will ensure the loans availed the domestic firms are deployed for the procurement of eco-friendly machinery and equipment that will be less harmful to the environment. In addition, there is need for the Nigeria government to examine the cost benefit of the FDI in respect to the impact on the environment, so that if the cost is greater than benefit, a trade agreement with the partner country should include the modalities of cushioning the effect on the environment. Lastly, as part of measure to mitigate carbon emissions in Nigeria, carbon pricing mechanism for the manufacturing firms' activities, and the program for nationwide social awareness to educate the public in respect of the detrimental cost of pollution should be integrated into environmental policies in the country.

Acknowledgements The authors fully acknowledged all the papers cited in this manuscript.

Data Availability Data used in this study can be found in the cited link.

\section{Compliance with Ethical Standards}

Conflict of interest The authors declare that there are no conflicts of interests regarding the publication of this paper.

Transparency The authors confirms that the manuscript is an honest, accurate, and transparent account of the study was reported; that no vital features of the study have been omitted; and that any discrepancies from the study as planned have been explained.

Ethical Approval This study follows all ethical practices during writing.

\section{References}

1. Abid M (2015) The close relationship between informal economic growth and carbon emissions in Tunisia since 1980: the (ir) relevance of structural breaks. Sustain Cities Soc 15:11-21

2. Acharyya J (2009) FDI, growth and the environment: evidence from India on $\mathrm{CO} 2$ emission during the last two decades. J Econ Dev 34:43-58

3. Adebayo TS, Awosusi AA, Eminer F (2020) Stock market-growth relationship in an emerging economy: empirical finding from ARDL-based bounds and causality approaches. J Econ Bus 3(2):903-916

4. Adebayo TS, Beton Kalmaz D (2020) Ongoing debate between foreign aid and economic growth in Nigeria: a wavelet analysis. Soc Sci Q. https://doi.org/10.1111/ssqu.12841

5. Adebayo TS (2020) New insights into export-growth nexus: wavelet and causality approaches. Asian J Econ Bus Account 15(12):32-44 
6. Ahmad M, Khan Z, Rahman Z et al (2018) Does financial development asymmetrically affect $\mathrm{CO} 2$ emissions in China? An application of the nonlinear autoregressive distributed lag (NARDL) model. Carbon Manag 9(6):631-644

7. Ahmad A, Zhao Y, Shahbaz M, Bano S, Zhang Z, Wang S, Liu Y (2016) Carbon emissions, energy consumption and economic growth: an aggregate and disaggregate analysis of the Indian economy. Energy Policy 96:131-143

8. Ahmad N, Du L, Lu J, Wang J, Li H-Z, Hashmi MZ (2017) Modelling the $\mathrm{CO} 2$ emissions and economic growth in Croatia: is there any environmental kuznets curve? Energy 123(March):164-172

9. Akinsola GD, Adebayo TS (2021) Investigating the causal linkage among economic growth, energy consumption and $\mathrm{CO} 2$ emissions in Thailand: an application of the wavelet coherence approach. Int J Renew Energy Dev 10(1):17-26

10. Akpan GE, Akpan UF (2012) Electricity consumption, carbon emissions and economic growth in Nigeria. Int J Energy Econ Policy 2(4):292

11. Al-Mulali U, Tang CF, Ozturk I (2015) Does financial development reduce environmental degradation? Evidence from a panel study of 129 countries. Environ Sci Pollut Res 22(19):14891-14900

12. Al-mulali U, Sab CNBC, Fereidouni HG (2012) Exploring the bi-directional long run relationship between urbanization, energy consumption, and carbon dioxide emission. Energy 46:156-167

13. Alom K, Uddin ANM, Islam N (2017) Energy consumption, C02 emissions, urbanization and financial development in Bangladesh: vector error correction model. J Glob Econ Manag Bus Res 9(4):178-189

14. Aminu A. M., (2005) Foreign Direct Investment and the Environment: Pollution Haven Hypothesis Revisited .Paper prepared for the Eight Annual Conference on Global Economic Analysis, Lübeck, Germany

15. Amri $F$ (2017) Carbon dioxide emissions, output, and energy consumption categories in Algeria. Environ Sci Pollut Res 24:14567-14578

16. Ang JB (2007) CO2 Emissions, energy consumption, and output in France. Energy Policy 35(10):4772-4778

17. Apergis N, Payne JE (2010) The emissions, energy consumption, and growth nexus: evidence from the commonwealth of independent states. Energy Policy 38:650-655

18. Asumadu-Sarkodie S, Owusu P (2016) The casual nexus between child mortality rate, fertility rate, GDP, household final consumption expenditure, and food production index. Cog Econ Financ 4(1):1191985

19. Asumadu-Sarkodie S, Sevinç Ç, Jayaweera HM (2016) A hybrid solar photovoltaic-wind turbine-rankine cycle for electricity generation in Turkish republic of Northern Cyprus. Cog Eng 3(1):1180740

20. Aye GC, Edoja PE (2017) Effect of economic growth on C02 emission in developing countries: evidence from a dynamic panel threshold model. Cog Econ Financ 5(1):1-22

21. Awosusi AA, Adebayo T, Ajayi T (2020) Dynamic aid-growth relationship in Nigeria: a two-gap approach. LAÜ Sos Bilim Derg 11(1):1-17

22. Bano S, Zhao Y, Ahmad A, Wang S, Liu Ya (2018) Identifying the impacts of human capital on carbon emissions in Pakistan. J Clean Prod 183(May):1082-1092

23. Begum RA, Sohag K, Abdullah S, Mastura S, Jaafar M (2015) $\mathrm{CO} 2$ Emissions, energy consumption, economic and population growth in Malaysia. Renew Sustain Energy Rev 41(January):594-601

24. Ben Jebli M, Ben Youssef S (2017) Renewable energy consumption and agriculture: evidence for cointegration and granger causality for Tunisian economy. Int J Sustain Dev World Ecol 24(2):149-158

25. Bekun FV, Agboola MO, Joshua U (2020) Fresh insight into the EKC hypothesis in Nigeria: accounting for total natural resources rent. Econom Green Energy 3(2):221-243

26. Chukwunonso Bosah P, Li S, AmpofoAkwasi Asante KMGD, Wang Z (2020) The nexus between electricity consumption, economic growth, and $\mathrm{CO} 2$ emission: an asymmetric analysis using nonlinear ARDL and nonparametric causality approach. Energies 13(5):1258

27. Charfeddine L, Kahia M (2019) Impact of renewable energy consumption and financial development on $\mathrm{CO} 2$ emissions and economic growth in the MENA region: a panel vector autoregressive (PVAR) analysis. Renew Energy 139:198-213

28. Charfeddine L, Khediri KB (2016) Financial development and environmental quality in UAE: cointegration with structural breaks. Renew Sustain Energy Rev 55:1322-1335

29. Chindo S, Abdulrahim A, Waziri SI, Huong WM, Ahmad AA (2015) Energy consumption, CO2 emissions and GDP in Nigeria. GeoJournal 80(3):315-322

30. Choi E, Heshmati A, Cho Y (2010) An empirical study of the relationships between $\mathrm{CO}_{2}$ emissions, economic growth and openness. IZA J 10(4):3-37

31. Clémençon R (2016) The two sides of the Paris climate agreement: Dismal failure or historic breakthrough? J Environ Dev 25(1):3-24

32. DFID (Department for International Development). (2009). Impact of climate change on Nigeria's economy

33. Dinda S, Coondoo D (2006) Income and emission: a panel databased cointegration analysis. Ecol Econ 57:167-181

34. Dritsaki C, Dritsaki M (2014) Causal relationship between energy consumption, economic growth and $\mathrm{CO} 2$ emissions: a dynamic panel data approach. Int J Energy Econ Policy 4(2):125

35. Ehigiamusoe KU, Lean HH (2019) Effects of energy consumption, economic growth, and financial development on carbon emissions: evidence from heterogeneous income groups. Environ Sci Pollut Res Int 26(22):22611-22624

36. Elum ZA, Momodu AS (2017) Climate change mitigation and renewable energy for sustainable development in Nigeria: a discourse approach. Renew Sustain Energy Rev 76:72-80

37. Farhani S, Ozturk I (2015) Causal relationship between $\mathrm{CO} 2$ emissions, real GDP, energy consumption, financial development, trade openness, and urbanization in Tunisia. Environ Sci Pollut Res 22:15663-15676

38. Farhani S, Rejeb JB (2012) Energy consumption, economic growth and $\mathrm{CO} 2$ emissions: evidence from panel data for MENA region. Int J Energy Econ Policy 2:71-81

39. Frankel J, Rose A (2002) An estimate of the effect of common currencies on trade and income. Quart J Econ 117(2):437-466

40. G€ok A (2020) The role of financial development on carbon emissions: a meta regression analysis. Environ Sci Pollut Res 27:11618-11636

41. Gurney KR, Mendoza DL, Zhou Y, Fischer ML, Miller CC, Geethakumar S, dela Rue du Can S (2009) High resolution fossil fuel combustion $\mathrm{CO} 2$ emission fluxes for the United States. Environ Sci Technol 43:5535-5541

42. Granger, C. W. J., \& Yoon, G. (2002). Hidden Cointegration. Department of economics discussion paper 2002-02, University of California, San Diego

43. Gujarati DN, Porter DC (1999) Essentials of econo-metrics. McGraw Hill, New York

44. Halicioglu F (2009) An econometric study of CO2 emissions, energy consumption, income and foreign trade in Turkey. Energy Policy 37(3):1156-1164

45. Han Ji, Du T, Zhang C, Qian X (2018) Correlation analysis of $\mathrm{CO} 2$ emissions, material stocks and economic growth 
nexus: evidence from Chinese provinces. J Clean Prod 180(April):395-406

46. Harbaugh WT, Levinson A, Wilson DM (2002) Reexamining the empirical evidence for an environmental Kuznets curve. Rev Econ Stat 84(3):541-551

47. Ibrahiem DM (2020) Do technological innovations and financial development improve environmental quality in Egypt? Environ Sci Pollut Res 27:10869-10881

48. Islam R, Ghani ABA, Mahyudin E (2017) Carbon dioxide emission, energy consumption, economic growth, population, poverty and forest area: evidence from panel data analysis. Int J Energy Econ Policy 7:99-106

49. Jardón A, Kuik O, Tol RSJ (2017) Economic growth and carbon dioxide emissions: an analysis of latin America and the Caribbean. Atmósfera 30(2):87-100

50. Javid M, Sharif F (2016) Environmental kuznets curve and financial development in Pakistan. Renew Sustain Energy Rev 54:406-414

51. Jiang C, Ma X (2019) The impact of financial development on carbon emissions: a Global Perspective. Sustainability 11(19):5241

52. Khan Z, Sisi Z, Siqun $Y$ (2019) Environmental regulations an option: Asymmetry effect of environmental regulations on carbon emissions using non-linear ARDL. Energy Sources Part A: Recovery Util Environ Eff 41(2):137-155

53. Karasoy A (2019) Drivers of carbon emissions in Turkey: considering asymmetric impacts. Environ Sci Pollut Res Int 26(9):9219-9231

54. Khan MK, Teng JZ, Khan MI (2019) Effect of energy consumption and economic growth on carbon dioxide emissions in Pakistan with dynamic ARDL simulations approach. Environ Sci Pollut Res 26(23):23480-23490

55. Khoshnevis Yazdi S, Khanalizadeh B (2017) Air pollution, economic growth and health care expenditure. Econ Res-Ekonomska istraživanja 30(1):1181-1190

56. Kim DD (2013) Does FDI inflow crowd out DI in Korea quest. J Econ Stud 30:605-622

57. Koçak $E$, Şarkgüneşi $A$ (2018) The impact of foreign direct investment on $\mathrm{CO} 2$ emissions in Turkey: new evidence from cointegration and bootstrap causality analysis. Environ Sci Pollut Res 25(1):790-804

58. Kong $Y$, Wei $F$ (2017) Financial development, financial structure and carbon emission. Environ Eng Manag J 16(7):1609-1622

59. Kutney, G. (2014). Carbon politics and the failure of the Kyoto protocol. Routledge. Retrieved from https://public.eblib.com/ choice/publicfullrecord.aspx? $p=1613788$

60. Katrakilidis C, Trachanas E (2012) What drives housing price dynamics in Greece: new evidence from asymmetric ARDL cointegration. Econ Model 29(4):1064-1069

61. Lau L-S, Choong C-K, Eng Y-K (2014) Carbon dioxide emission, institutional quality, and economic growth: empirical evidence in Malaysia. Renew Energy 68:276-281

62. Lardic S, Mignon V (2008) Oil prices and economic activity: an asymmetric cointegration approach. Energy Econ 30(3):847-855

63. Maku OE, Adegboyega SB, Oyelade AO (2018) The impact of foreign direct investment on CO2 emission in Nigeria (19802014). Int J Sci Eng Res 9(2):2061-2077

64. Mikayilov JI, Galeotti M, Hasanov FJ (2018) The impact of economic growth on $\mathrm{CO} 2$ emissions in Azerbaijan. J Clean Prod 197:1558-1572

65. Mirza FM, Kanwal A (2017) Energy consumption, carbon emissions and economic growth in Pakistan: dynamic causality analysis. Renew Sustain Energy Rev 72:1233-1240
66. Moghadam HE, Dehbashi V (2018) The impact of financial development and trade on environmental quality in Iran. Empir Econ 54(4):1777-1799

67. Mohiuddin O, Asumadu-Sarkodie S, Obaidullah M (2016) The relationship between carbon dioxide emissions, energy consumption, and GDP: a recent evidence from Pakistan. Cog Eng 3(1):1210491

68. Malik MY, Latif K, Khan Z, Butt HD, Hussain M, Nadeem MA (2020) Symmetric and asymmetric impact of oil price, FDI and economic growth on carbon emission in Pakistan: evidence from ARDL and non-linear ARDL approach. Sci Total Environ 726:138421

69. Musibau HO, Shittu WO, Ogunlana FO (2020) The relationship between environmental degradation, energy use and economic growth in Nigeria: new evidence from non-linear ARDL. Int J Energy Sect Manag. https://doi.org/10.1108/IJESM -04-2019-0016

70. Narayan PK, Narayan S (2010) Carbon dioxide emissions and economic growth: panel data evidence from developing countries. Energy policy 38(1):661-666

71. Nasir MA, Huynh TLD, Tram HTX (2019) Role of financial development, economic growth and foreign direct investment in driving climate change: a case of emerging ASEAN. J Environ Manag 242:131-141

72. Nasreen S, Anwar S, Ozturk I (2017) Financial stability, energy consumption and environmental quality: evidence from South Asian economies. Renew Sustain Energy Rev 67:1105-1122

73. Odugbesan JA, Rjoub H (2019) Relationship among HIV/AIDS prevalence, human capital, good governance, and sustainable development: empirical evidence from Sub-Saharan Africa. Sustainability 11(5):1348

74. Odugbesan JA, Rjoub H (2020) Relationship among economic growth, energy consumption, $\mathrm{CO} 2$ emission, and urbanization: evidence from MINT countries. SAGE Open 10(2):2158244020914648

75. Omoke PC, Opuala-Charles S, Nwani C (2020) Symmetric and asymmetric effects of financial development on carbon dioxide emissions in Nigeria: evidence from linear and nonlinear autoregressive distributed lag analyses. Energy Explor Exploit. https://doi.org/10.1177/0144598720939377

76. Organization of the Petroleum Exporting Countries (OPEC) (2019), Annual Statistical Bulletin. Available at: https://asb. opec.org/index.php/data-download (accessed 02 August 2020)

77. Owusu P, Asumadu-Sarkodie S (2016) A review of renewable energy sources, sustainability issues and climate change mitigation. Cog Eng 3(1):1167990

78. Onyibor K, Bah Si, Tomiwa A (2018) Aid-growth relationship: evidence from a co-integration analysis for the five poorest countries of the world. LAÜ Sos Bil Derg 9(2):121-137

79. PACJA (Pan African Climate Justice Alliance). (2009). The economic cost of climate change in Africa

80. Peng, S., \& Sun, Z. (2010). An econometric study of CO2 emissions, energy consumption and economic growth in China. In 2010 International Conference on Mechanic Automation and Control Engineering (MACE) (pp. 1805-1808). IEEE. Retrieved from https://ieeexplore.ieee.org/xpls/abs_all.jsp?arnum ber $=5536531$

81. Pesaran MH, Shin Y, Smith RJ (2001) Bounds testing approaches to the analysis of level relationships. J Appl Econ 16(3):289-326

82. Pesaran MH, Shin Y (1998) An autoregressive distributed-lag modelling approach to cointegration analysis. Econ Soc Monogr 31:371-413

83. Pesaran MH, Shin Y, Smith RP (1999) Pooled mean group estimation of dynamic heterogeneous panels. J Am Stat Assoc 94(446):621-634 
84. Riti JS, Shu Y (2016) Renewable energy, energy efficiency, and eco-friendly environment (RE5) in Nigeria. Energy Sustain Soc 6(1):13

85. Riti JS, Song D, Shu Y, Kamah M (2017) Decoupling CO2 emission and economic growth in China: is there consistency in estimation results in analyzing environmental Kuznets curve? J Clean Prod 166:1448-1461

86. Robledo JC, Olivares W (2013) Relationship between CO2 emissions, energy consumptio. Semest Económico 16:45-66

87. Saboori B, Sulaiman J, Mohd S, (2012) Economic growth and $\mathrm{CO} 2$ emissions in Malaysia: a cointegration analysis of the environmental kuznets curve. Energy Policy 51:184-191

88. Saidi K, Mbarek MB (2016) Nuclear energy, renewable energy, $\mathrm{CO} 2$ emissions, and economic growth for nine developed countries: evidence from panel granger causality tests. Prog Nucl Energy 88:364-374

89. Sarwar S, Shahzad U, Chang D, Tang B (2019) Economic and non-economic sector reforms in carbon mitigation: empirical evidence from Chinese provinces. Struct Change Econ Dyn 49:146-154

90. Shabestari, Bazarcheh Negin, (2018). Energy Consumption, CO2 Emissions and Economic Growth : Sweden's Case. https ://www.diva-portal.org/smash/record.jsf?pid=diva2\%3A121 4695\&dswid $=1476$

91. Shahbaz M, Hye QMA, Tiwari AK et al (2013) Economic growth, energy consumption, financial development, international trade and $\mathrm{CO} 2$ emissions in Indonesia. Renew Sustain Energy Rev 25:109-121

92. Shahbaz M, Shahzad SJH, Ahmad N et al (2016) Financial development and environmental quality: the way forward. Energy Policy 98:353-364

93. Shahbaz M, Sarwar S, Chen W, Malik MN (2017) Dynamics of electricity consumption, oil price and economic growth: global perspective. Energy Policy 108:256-270

94. Shahbaz M, Van Hoang TH, Mahalik MK, Roubaud D (2017) Energy consumption, financial development and economic growth in India: New evidence from a nonlinear and asymmetric analysis. Energy Econom 63:199-212

95. Shahiduzzaman Md, Layton A (2015) Changes in CO2 emissions over business cycle recessions and expansions in the United States: a decomposition analysis. Appl Energy 150:25-35

96. Sheldon T (2017) Asymmetric effects of the business cycle on carbon dioxide emissions: a new layer of climate change uncertainty. Energy Econ 61:289-297

97. Shin Y, Yu B, Greenwood-Nimmo M (2014) Modelling asymmetric cointegration and dynamic multipliers in a nonlinear ARDL framework. Festschr Honor Peter Schmidt 7(10):281-314

98. Sterpu M, Soava G, Mehedintu A (2018) Impact of economic growth and energy consumption on greenhouse gas emissions: testing environmental curves hypotheses on EU countries. Sustainability 10:14
99. Sy A, Tinker T, Derbali A, Jamel L (2016) Economic growth, financial development, trade openness and $\mathrm{C02}$ emissions in European countries. Afr J Account Audit Financ 5(2):1226-1235

100. Schorderet $Y$ (2003) Asymmetric cointegration. Université de Genève/Faculté des sciences économiques et sociales, Genève

101. Tamazian A, Chousa JP, Vadlamannati KC (2009) Does higher economic and financial development lead to environmental degradation: evidence from BRIC countries. Energy policy 37(1):246-253

102. Toumi S, Toumi H (2019) Asymmetric causality among renewable energy consumption, $\mathrm{CO} 2$ emissions, and economic growth in KSA: evidence from a non-linear ARDL model. Environ Sci Pollut Res 26(16):16145-16156

103. U.S. Energy Information Administration (2016). International Energy Output 2016. https://www.eia.gov/

104. Waheed R, Chang D, Sarwar S, Chen W (2018) Forest, agriculture, renewable energy, and CO2 emission. J Clean Prod 172:4231-4238

105. Wang S, Li Q, Fang C, Zhou C (2016) The relationship between economic growth, energy consumption, and $\mathrm{CO} 2$ emissions: empirical evidence from China. Sci Total Environ 542:360-371

106. World Bank. (2020). World development indicators. https:// data.worldbank.org/country/nigeria

107. World Bank Report. (2007). How do different countries. "Growthand $\mathrm{CO} 2$ emissions: How do different countries fare?". Retrieved August 6, 2020, from https://www3.imperial. ac.uk/ pls/portallive/docs/1/34721711.PDF

108. Xu Z, Baloch MA, Meng F et al (2018) Nexus between financial development and $\mathrm{CO} 2$ emissions in Saudi Arabia: analyzing the role of globalization. Environ Sci Pollut Res 25(28):28378-28390

109. $X u B$, Lin $B(2015)$ How industrialization and urbanization process impacts on $\mathrm{CO} 2$ emissions in China: Evidence from nonparametric additive regression models. Energy Economics 48(March):188-202

110. Yanchun, Y. (2010). FDI and China's carbon dioxide emissions 1978-2008. In Proceedings of the 7th international conference on innovation andmanagement (pp. 289-293). Wuhan University of Technology

111. Yang G, Sun T, Wang J, Li X (2015) Modeling the nexus between Carbon dioxide emissions and economic growth. Energy Policy 86(November):104-117

112. York, Richard, and Ryan Light. 2017. "Directional Asymmetry in Sociological Analyses." Socius 3. Retrieved August 16, 2020 (http://journals.sagepub.com/doi/abs/https://doi. org/10.1177/2378023117697180)

113. Yuxiang K, Chen Z (2010) financial development and environmental performance: Evidence from China. Environ Dev Econ 16(1):1-19

Publisher's Note Springer Nature remains neutral with regard to jurisdictional claims in published maps and institutional affiliations. 